\title{
Prognostic value of microRNAs in osteosarcoma: a meta-analysis
}

\author{
Yun Hak Kim ${ }^{1,2, *}$, Tae Sik Goh ${ }^{1,3, *}$, Chi-Seung Lee $^{4}$, Sae Ock Oh${ }^{2}$, Jeung Il Kim ${ }^{3}$, \\ Seung Hyeon Jeung ${ }^{3}$, Kyoungjune Pak ${ }^{1,5}$ \\ ${ }^{1}$ BEER, Busan Society of Evidence-Based Medicine and Research, Busan, Republic of Korea \\ ${ }^{2}$ Department of Anatomy, School of Medicine, Pusan National University, Yangsan, Gyeongnam, Republic of Korea \\ ${ }^{3}$ Department of Orthopaedic Surgery and Biomedical Research Institute, Pusan National University Hospital, Busan, Republic \\ of Korea \\ ${ }^{4}$ Biomedical Research Institute, Pusan National University Hospital and School of Medicine, Pusan National University, Busan, \\ Republic of Korea \\ ${ }^{5}$ Department of Nuclear Medicine and Biomedical Research Institute, Pusan National University Hospital, Busan, Republic of \\ Korea \\ *These authors have contributed equally in this work
}

Correspondence to: Kyoungjune Pak, email: ilikechopin@me.com

Keywords: microRNA, osteosarcoma, prognosis, meta-analysis

Received: November 01, $2016 \quad$ Accepted: December 01, 2016 Published: January 02, 2017

\section{ABSTRACT}

BACKGROUND: Osteosarcoma is the most common primary bone malignancy. We meta-analyzed the prognostic value of altered miRNAs in patients with osteosarcoma.

METHODS: Sources from MEDLINE (from inception to August 2016) and EMBASE (from inception to August 2016) were searched. Studies of osteosarcoma with results of miRNA and studies that reported survival data were included and two authors performed the data extraction independently. Any discrepancies were resolved by a consensus. The outcome was overall survival and event-free survival assessed using hazard ratios (HRs).

RESULTS: After reviewing the full text of 65 articles, 25 studies including 2,278 patients were eligible in this study. The pooled HR for deaths was 1.40 (95\% confidence interval $[\mathrm{CI}] 1.01-1.94, p=0.04)$ with random-effects model $\left(X^{2}=113.08\right.$, $p<0.00001, I^{2}=79 \%$ ) for patients of osteosarcoma with lower expression of miRNA. However, the pooled HR for events was not significant (HR 0.97, 0.63-1.48, $p=0.87$, $X^{2}=72.65, p<0.00001, I^{2}=79 \%$ ). In pathway analysis of miRNAs, miRNA449a, 199-5p, 542-5p have common target genes.

CONCLUSIONS: Expression level of miRNA in patients of osteosarcoma is important as a prognostic factor.

\section{INTRODUCTION}

Osteosarcoma is the most common primary bony malignancies and first leading cause of sarcoma-related deaths in children and young adults. It mainly occurs in metaphyseal area of distal femur and proximal tibia. Osteosarcoma is highly aggressive tumor and most likely metastasizes to the lung [1]. Even though the survival rate has modestly increased over the last 2 decades by implicating radiotherapy and neo-adjuvant chemotherapy, five-year survival rate of metastatic osteosarcoma still remains in the range of $15 \%$ to $30 \%$. For localized osteosarcoma which can be totally resectable, the five-year survival rate increases up to $70 \%$ [2]. Hence, excavating novel prognostic biomarkers of osteosarcoma is strongly needed to detect tumor at early stage. They will contribute to select better treatment options in earlier stages and predict the outcome more accurately.

MicroRNAs (miRNAs) are a class of small noncoding RNAs, which could interfere translation of many proteins after gene transcription [3]. Previous studies revealed that they are implicated on a variety of physiological processes including cellular differentiation, apoptosis, angiogenesis and cell proliferation [4]. Additionally, miRNAs play a pivotal role in tumorigenesis that can act either as tumor suppressor genes or 
oncogenes [3, 5]. Level of miRNAs expressed in several malignancies, including lung, kidney, liver, and cervical cancer were significantly different from that of normal tissue $[6,7]$. Recent researches have demonstrated that various miRNAs are also altered in osteosarcoma tissue or blood sample [8]. These discoveries may indicate that miRNA could be potential prognostic biomarkers of osteosarcoma. Therefore, we meta-analyzed the prognostic value of altered miRNAs in patients with osteosarcoma.

\section{RESULTS}

\section{Study characteristics}

The electronic search identified 289 articles. NonEnglish language articles $(n=3)$, non-human studies $(n=13)$, conference abstracts $(n=34)$, and 174 studies that did not meet the inclusion criteria based on their title and abstract were excluded. After reviewing the full text of 65 articles, 25 studies including 2,278 patients were eligible for inclusion in the study. The detailed procedure is shown in Figure 1. The studies included in this metaanalysis reported the prognostic value of 26 miRNAs in patients with osteosarcoma. Twenty-five studies assessing 26 miRNA expressions were included in the meta-analysis [9-33]. The prognostic value of miRNA expressions was assessed by analyzing overall survival (OS) in 2,278 patients, event free survival (EFS) in 1,569 patients. Visual inspection of the funnel plot suggested no evidence of publication bias (Figure $2 \mathrm{~B}$ and $3 \mathrm{~B}$ ). The study characteristics are summarized in Table 1.

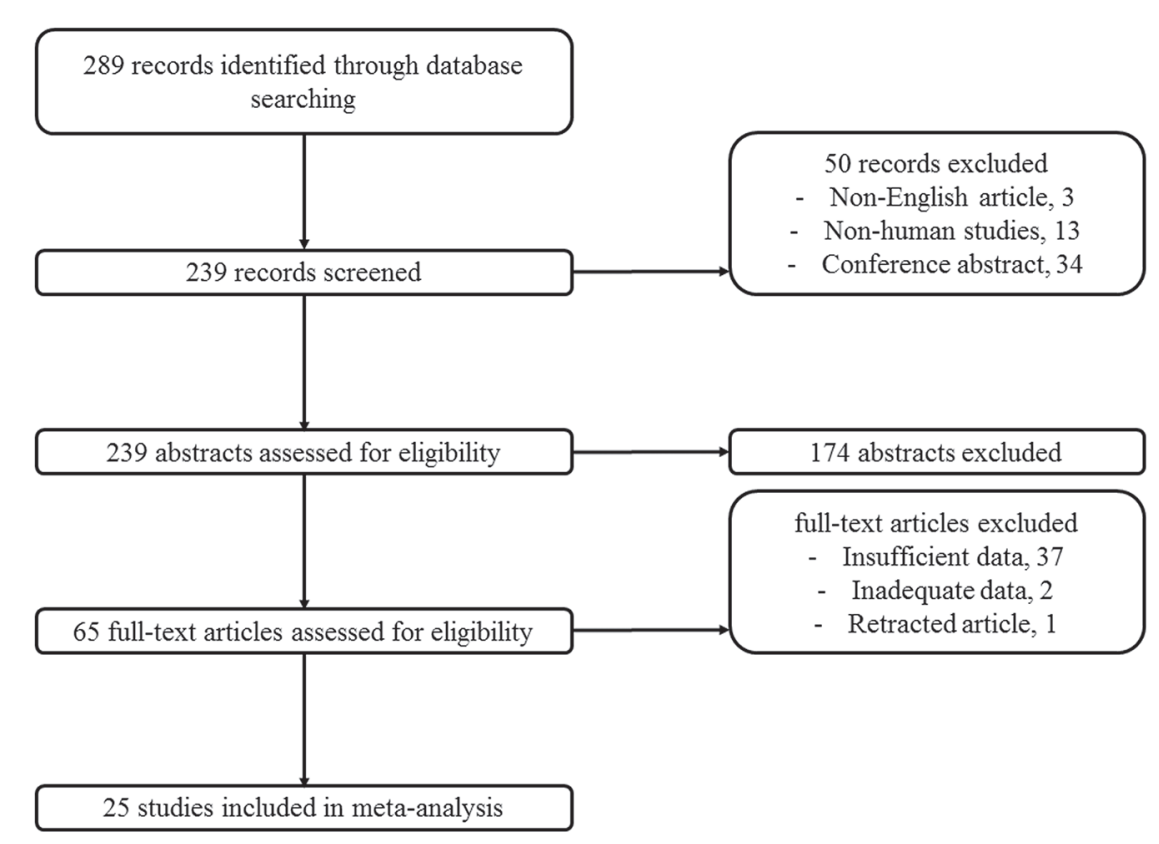

Figure 1: Flow chart.
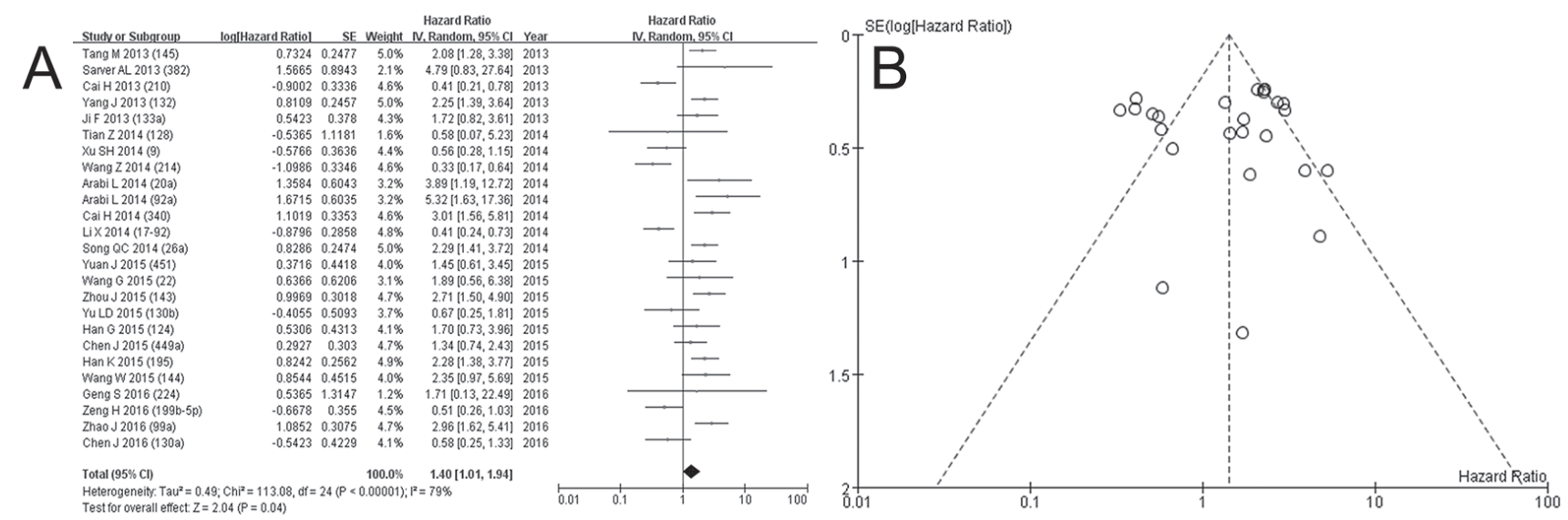

Figure 2: Forest plot A. and funnel plot B. for deaths of low expression of miRNA in osteosarcoma. 
Table 1: Studies included in this meta-analysis

\begin{tabular}{|c|c|c|c|c|c|c|c|c|c|c|}
\hline Author & $\begin{array}{c}\text { Year of } \\
\text { publication }\end{array}$ & Country & miRNA & $\begin{array}{c}\text { No. of } \\
\text { patients }\end{array}$ & Stage & $\begin{array}{c}\text { Follow-up } \\
\text { (months) }\end{array}$ & Endpoints & $\begin{array}{c}\text { Expression } \\
\text { associates } \\
\text { with poor } \\
\text { prognosis }\end{array}$ & $\begin{array}{l}\text { Assay } \\
\text { method }\end{array}$ & Sample \\
\hline Cai H [10] & 2013 & China & 210 & 92 & - & $105^{\mathrm{a}}$ & OS, EFS & High & RT-PCR & Tissue \\
\hline Li X [19] & 2014 & China & $\begin{array}{l}17-92 \\
\text { cluster }\end{array}$ & 117 & I-III & $55^{\mathrm{a}}$ & OS, EFS & High & RT-PCR & Tissue \\
\hline Tian Z [23] & 2014 & China & 128 & 100 & - & $38.89^{\mathrm{a}}$ & OS, EFS & High & RT-PCR & Tissue \\
\hline $\mathrm{Xu} \mathrm{SH} \mathrm{[27]}$ & 2014 & China & 9 & 79 & I-III & $60^{\mathrm{a}}$ & OS & High & RT-PCR & Tissue \\
\hline Wang Z [26] & 2014 & China & 214 & 92 & - & $107^{\mathrm{a}}$ & OS, EFS & High & RT-PCR & Tissue \\
\hline $\begin{array}{l}\text { Cheng DD } \\
{[14]}\end{array}$ & 2015 & China & $542-5 p$ & 40 & - & 40 & EFS & High & RT-PCR & Tissue \\
\hline Yu LD [29] & 2015 & China & $130 \mathrm{~b}$ & 68 & I-III & 36 & OS, EFS & High & RT-PCR & Tissue \\
\hline Chen J [12] & 2016 & China & $130 \mathrm{a}$ & 86 & I-IV & $60^{\mathrm{a}}$ & OS, EFS & High & RT-PCR & Tissue \\
\hline Zeng H [31] & 2016 & China & $199 b-5 p$ & 98 & I-IV & $60^{\mathrm{b}}$ & OS, EFS & High & RT-PCR & Tissue \\
\hline Yang J [28] & 2013 & China & 132 & 166 & II-III & $105^{\mathrm{a}}$ & OS, EFS & Low & RT-PCR & Tissue \\
\hline Tang M [22] & 2013 & China & 145 & 166 & II-III & $100^{\mathrm{a}}$ & OS, EFS & Low & RT-PCR & Tissue \\
\hline $\begin{array}{l}\text { Sarver AL } \\
{[20]}\end{array}$ & 2013 & USA & 382 & 8 & - & $194^{\mathrm{a}}$ & OS, EFS & Low & RT-PCR & Tissue \\
\hline Ji F [18] & 2013 & China & $133 \mathrm{a}$ & 92 & I-III & $60^{\mathrm{a}}$ & OS & Low & RT-PCR & Tissue \\
\hline Song QC [21] & 2014 & China & $26 \mathrm{a}$ & 144 & II-III & $140^{\mathrm{a}}$ & OS, EFS & Low & RT-PCR & Tissue \\
\hline Cai H [11] & 2014 & China & 340 & 92 & - & $100^{\mathrm{a}}$ & OS, EFS & Low & RT-PCR & Tissue \\
\hline Arabi L [9] & 2014 & Switzerland & $20 \mathrm{a}$ & 57 & - & 112 & OS & Low & RT-PCR & Tissue \\
\hline Arabi L [9] & 2014 & Switzerland & $92 a$ & 57 & - & 112 & OS & Low & RT-PCR & Tissue \\
\hline Zhou J [33] & 2015 & China & 143 & 45 & - & $36^{\mathrm{c}}$ & OS & Low & RT-PCR & Tissue \\
\hline Yuan J [30] & 2015 & China & 451 & 118 & II-III & $80^{\mathrm{a}}$ & OS, EFS & Low & RT-PCR & Tissue \\
\hline Wang W [25] & 2015 & China & 144 & 67 & I-IV & $80^{\mathrm{a}}$ & OS & Low & RT-PCR & Tissue \\
\hline Wang G [24] & 2015 & China & 22 & 52 & I-IV & $60 \mathrm{c}$ & OS, EFS & Low & RT-PCR & Tissue \\
\hline Han K [17] & 2015 & China & 195 & 107 & II-III & $90^{\mathrm{a}}$ & OS & Low & RT-PCR & Tissue \\
\hline Han G [16] & 2015 & China & 124 & 105 & II-III & $80^{\mathrm{a}}$ & OS & Low & RT-PCR & Tissue \\
\hline Chen J [13] & 2015 & China & $449 \mathrm{a}$ & 60 & I-III & $60^{\mathrm{b}}$ & OS & Low & RT-PCR & Tissue \\
\hline Zhao J [32] & 2016 & China & $99 a$ & 130 & II-III & $60^{\mathrm{a}}$ & OS, EFS & Low & RT-PCR & Tissue \\
\hline Geng S [15] & 2016 & China & 224 & 40 & - & 60 & OS & Low & RT-PCR & Tissue \\
\hline
\end{tabular}

- Follow-up; 'amedian, 'beterogeneity of logrank test, ${ }^{\mathrm{c}}$ mean

- OS, overall survival; EFS, event free survival; RT-PCR, reverse transcription polymerase chain reaction

\section{miRNA expression and prognosis of osteosarcoma}

To analyze the prognostic value of low expression of miRNA in osteosarcoma, forest plots with OS and EFS are depicted in Figure 2 and 3. The pooled hazard ratio (HR) for deaths was 1.40 (95\% confidence interval [CI] $1.01-1.94, p=0.04)$ with random-effects model $\left(\chi^{2}=113.08\right.$, $p<0.00001, \mathrm{I}^{2}=79 \%$ ), which means more deaths with lower expression of miRNA in osteosarcoma. However, the pooled HR for events did not show the significant value (HR 0.97, 0.63-1.48, $p=0.87, \chi^{2}=72.65, p<0.00001$, $\mathrm{I}^{2}=79 \%$ ). Due to heterogeneity in pooled analysis of miRNA, we performed a subgroup analysis according to the expression level of miRNA. The HRs were calculated on the basis of low expression of miRNA, which means $\mathrm{HR}>1$ and $<1$ implied poor and good prognosis for patients with low miRNA expression. 
Table 2: Subgroup analysis according to miRNA expression with prognosis.

\begin{tabular}{|c|c|c|c|c|c|c|}
\hline & $\begin{array}{l}\text { No. of } \\
\text { studies }\end{array}$ & miRNA & HR & $\begin{array}{l}95 \% \mathrm{CI} \\
\text { of HR }\end{array}$ & $\begin{array}{l}\text { Heterogeneity } \\
\qquad I^{2}(\%)\end{array}$ & Model used \\
\hline \multicolumn{7}{|c|}{$\begin{array}{l}\text { Worse prognosis } \\
\text { with high miRNA } \\
\text { expression }\end{array}$} \\
\hline OS & 8 & $\begin{array}{c}210,17-92,128,9,214,130 b \\
130 a, 199 b-5 p\end{array}$ & 0.46 & $0.35-0.60$ & 0 & Fixed effect \\
\hline EFS & 8 & $\begin{array}{c}210,17-92,128,214,542-5 p \\
130 b, 130 a, 199 b-5 p\end{array}$ & 0.46 & $0.35-0.60$ & 0 & Fixed effect \\
\hline \multicolumn{7}{|c|}{$\begin{array}{l}\text { Worse prognosis } \\
\text { with low miRNA } \\
\text { expression }\end{array}$} \\
\hline OS & 16 & $\begin{array}{c}132,145,382,133 \mathrm{a}, 26 \mathrm{a}, 340 \\
20 \mathrm{a}, 92 \mathrm{a}, 143,451,144,22 \\
195,124,449 \mathrm{a}, 99 \mathrm{a}, 224\end{array}$ & 2.25 & $1.90-2.66$ & 0 & Fixed effect \\
\hline EFS & 8 & $\begin{array}{c}132,145,382,26 \mathrm{a}, 340,451 \\
22,99 \mathrm{a}\end{array}$ & 2.05 & $1.67-5.18$ & 0 & Fixed effect \\
\hline
\end{tabular}

- HR, hazard ratio; OS, overall survival; EFS, event free survival

\section{A. Worse prognosis with high miRNA expression}

High expressions of miRNA210, 17-92 cluster, 128, 9, 214, 542-5p, 130b, 130a, 199b-5p were associated with poor prognosis of osteosarcoma patients, [10, 12, 14, 19, 23, 26, 27, 29, 31]. Eight studies were included to analyze OS with miRNA210, 17-92 cluster, 128, 9, 214, 130b, 130a, $199-5 p$ in 732 patients $[10,12,19,23,26,27,29,31]$. The HR ranged between 0.33 and 0.67 with a pooled HR for deaths of $0.45(0.35-0.60, p<0.00001)$ with low expression of miRNA, and the test for heterogeneity gave no significant results $\left(\chi^{2}=2.47, p=0.93, \mathrm{I}^{2}=0 \%\right)$ (Table 2$)$. The EFS was analyzed with miRNA210, 17-92 cluster, 128, 214, 5425p, 130b, 130a, 199b-5p based on 8 studies including 693 patients $[10,12,14,19,23,26,29,31]$. The pooled HR of high miRNA for adverse events was 0.46 with a range from 0.30 to $0.71(0.35-0.60, p<0.00001)$, and the test for heterogeneity gave no significant results $\left(\chi^{2}=4.37, p=0.74\right.$, $\mathrm{I}^{2}=0 \%$ ) (Table 2). The forest plots for OS and EFS of high miRNA with worse prognosis are shown in Figure 4.

\section{B. Worse prognosis with low miRNA expression}

Low expression of miRNA132, 145, 382, 133a, 26a, 340, 20a, 92a, 143, 451, 144, 22, 195, 124, 449a, 99a, 224 were found to be associated with a poor prognosis $[9,11$, 13, 15-18, 20-22, 24, 25, 28, 30, 32, 33]. Sixteen studies analyzed OS with miRNA132, 145, 382, 133a, 26a, 340, 20a, 92a, 143, 451, 144, 22, 195, 124, 449a, 99a, 224 in 1,506 patients $[9,11,13,15-18,20-22,24,25,28,30,32$,
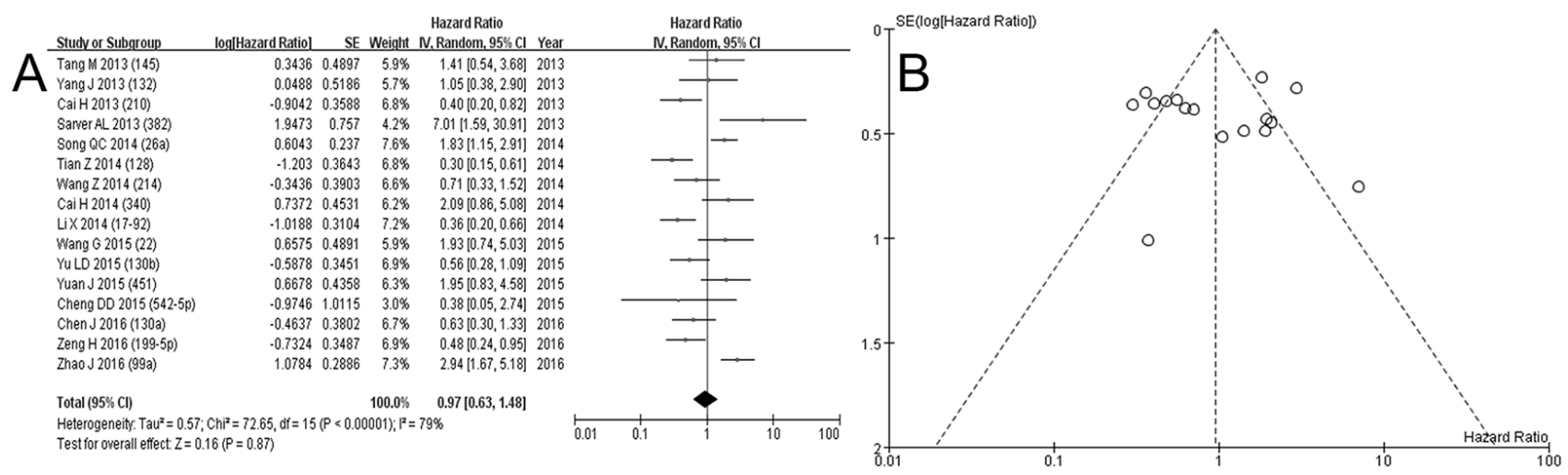

Figure 3: Forest plot A. and funnel plot B. for events of low expression of miRNA in osteosarcoma. 




Figure 4: Subgroup analysis: worse prognosis with high expression of miRNA; forest plots for deaths A. and events B. of low expression of miRNA in osteosarcoma.

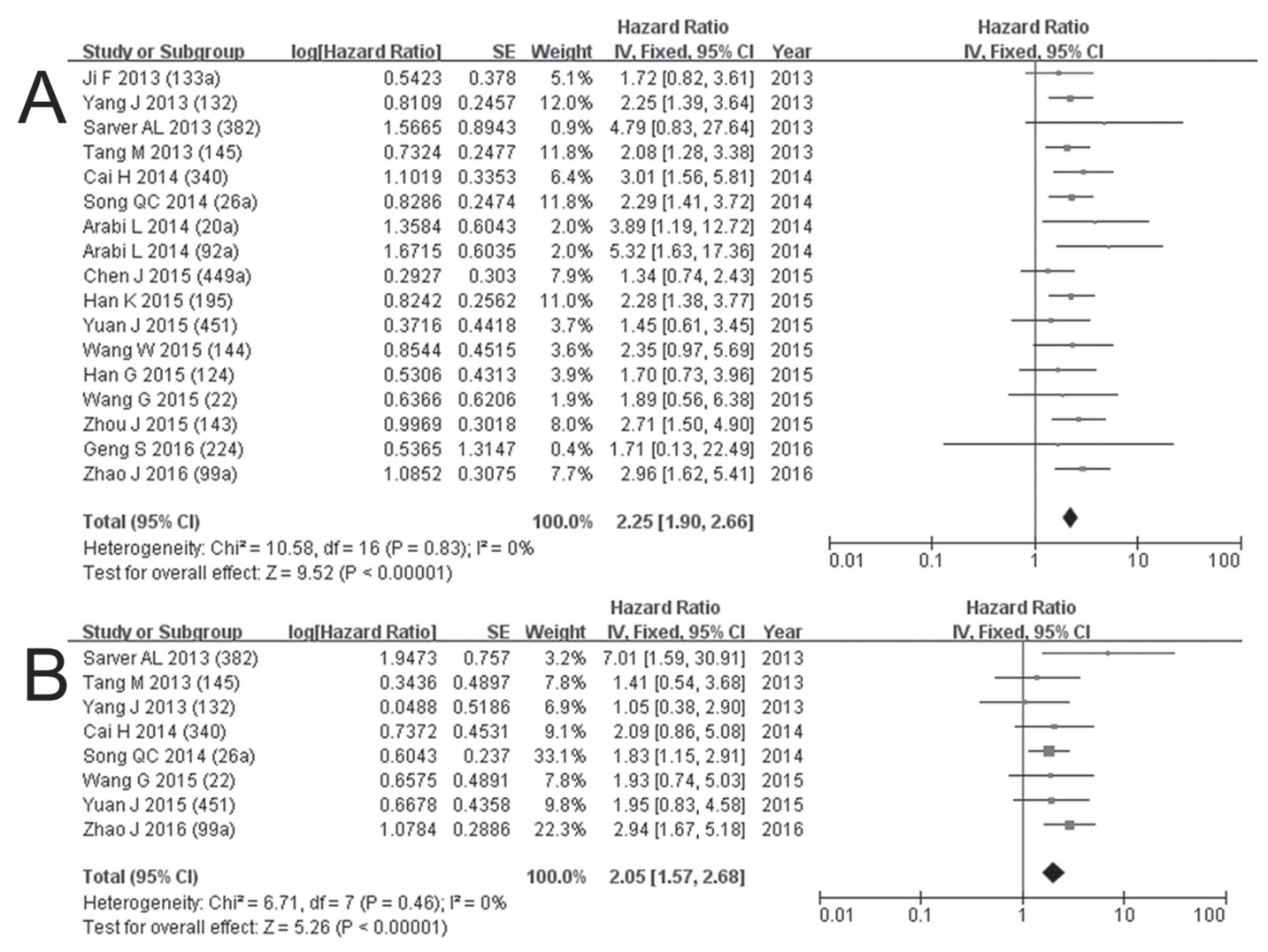

Figure 5: Subgroup analysis: worse prognosis with low expression of miRNA; forest plots for deaths A. and events B. of low expression of miRNA in osteosarcoma. 
33], and eight studies (miRNA132, 145, 382, 26a, 340, $451,22,99 \mathrm{a})$ containing 876 patients that reported EFS were included to calculate the combined HRs [11, 20-22, 24, 28, 30, 32]. The HR for deaths ranged widely between 1.34 and 5.32 with a combined HR of 2.25 (1.90-2.66, $p<0.00001)$, and the pooled HR for events was 2.05 with a range from 1.05 to $7.01(1.57-2.68, p<0.00001)$. There was no significant heterogeneity $\left(\mathrm{OS}: \chi^{2}=10.58, \mathrm{p}=0.83\right.$, $\mathrm{I}^{2}=0 \%$, EFS: $\chi^{2}=6.71, p=0.46, \mathrm{I}^{2}=0 \%$ ). The forest plots for OS and EFS of low miRNA with worse prognosis are shown in Figure 5.

\section{Pathway analysis of miRNAs}

In a pathway analysis of miRNAs using mirPath v3.0 based on Tarbase, KEGG and GO, miRNA449a, 199-5p, $542-5 p$ have target genes and signaling pathways, but others do not have known targets (Figure 6 and 7, Table 3) [34].

\section{DISCUSSION}

This study evaluated the prognostic value of miRNA in patients with osteosarcoma. As we described above, the combined HR of OS from the included studies was $1.40(1.01-1.94, p=0.04)$, which provided that low expression of miRNAs was related with shorter OS in patients with osteosarcoma. However, the combined HR of EFS was not significant. Due to heterogeneity in pooled analysis of miRNA, we performed a subgroup analysis according to the expression level of miRNA. For a more detailed analysis, we performed a subgroup analysis according to miRNA expressions (high or low) related with poor prognosis. High expression of miRNA 210, 17-92 cluster, 128, 9, 214, 542-5p, 130b, 130a, and $199 \mathrm{~b}-5 \mathrm{p}$ and low expression of miRNA 132, 145, 382, 133a, 26a, 340, 20a, 92a, 143, 451, 144, 22, 195, 124, 449a, 99a, 224 were associated with a poor prognosis of either deaths or events.
The possible role of miRNAs during osteosarcomagenesis is also investigated. Altered or aberrant expression of miRNA, its function during tumorigenesis, and potential target genes are summarized in Table 4. Nine miRNAs (miRNA 210, 17-92 cluster, 128, 9, 214, 542-5p, 130b, 130a, and 199b-5p) whose expression level correlated with poor prognosis function as an oncogene in osteosarcoma. Of that, miRNA 210 contributes its action in tumor initiation. miRNA 17-92 cluster, 214, 130b have been reported as they progress early stage osteosarcoma into advanced stage. And miRNA 9, 130a are associated with metastasis. On the contrary, 17 miRNAs $(132,145,382,133 \mathrm{a}, 26 \mathrm{a}, 340$, 20a, 92a, 143, 451, 144, 22, 195, 124, 449a, 99a, 224) function as a tumor suppressor gene, which expressed low level when they were related with worse outcome. Among these miRNAs, miRNA 382, 133a, 26a, 340, 143, 144, 195 have shown an anti-metastatic activity. Especially, miRNA 133a, 143 could be utilized as a future therapeutic target for lung metastasis. Moreover, miRNA 132, 145, 92a might act as a therapeutic standard for chemotherapy.

This is the first meta-analysis that evaluate the prognostic value of miRNAs in osteosarcoma. We demonstrated the association of the outcomes (OS, EFS) of osteosarcoma and level of miRNA expression. In addition, we measured HRs as the effectiveness endpoint in the current study. We did not measured the odds ratios or risk ratios whether these values represent only crosssectional cumulative estimate and do not including the time factor [35]. Hence, HRs are most appropriate for our report which analyze time-to-event outcomes. The type of samples was homogenous. All of the samples which were experimented in included studies were obtained from tumor tissue of osteosarcoma patients. This might be increased reliability and decreased heterogeneity of our study. We excluded studies using serum or plasma because there were a few studies about serum or circulating miRNAs in patients with osteosarcoma [36,

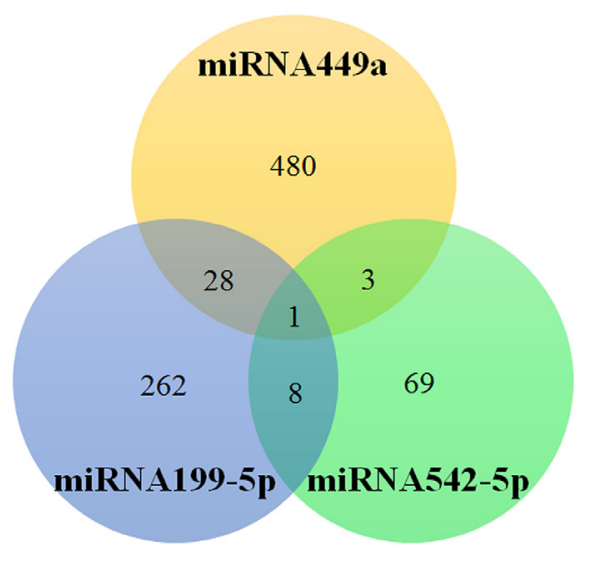

Figure 6: The number of target genes of miRNA449a, 199-5p and 542-5p. 
37]. However, there are increasing interest in circulating miRNAs due to their comfortable accessibility by drawing patient's blood compared to miRNAs of tissue from operation and they could be easily repeated and monitored through.
From the pathway analysis, we found that several common targets and pathways of miRNA199b-5p, 449a and $542-5 \mathrm{p}$, for example, fatty acid biosynthesis (target gene: Fatty Acid Synthase (FASN)) (Table 3). FASN is known as a therapeutic target in the treatment of

B
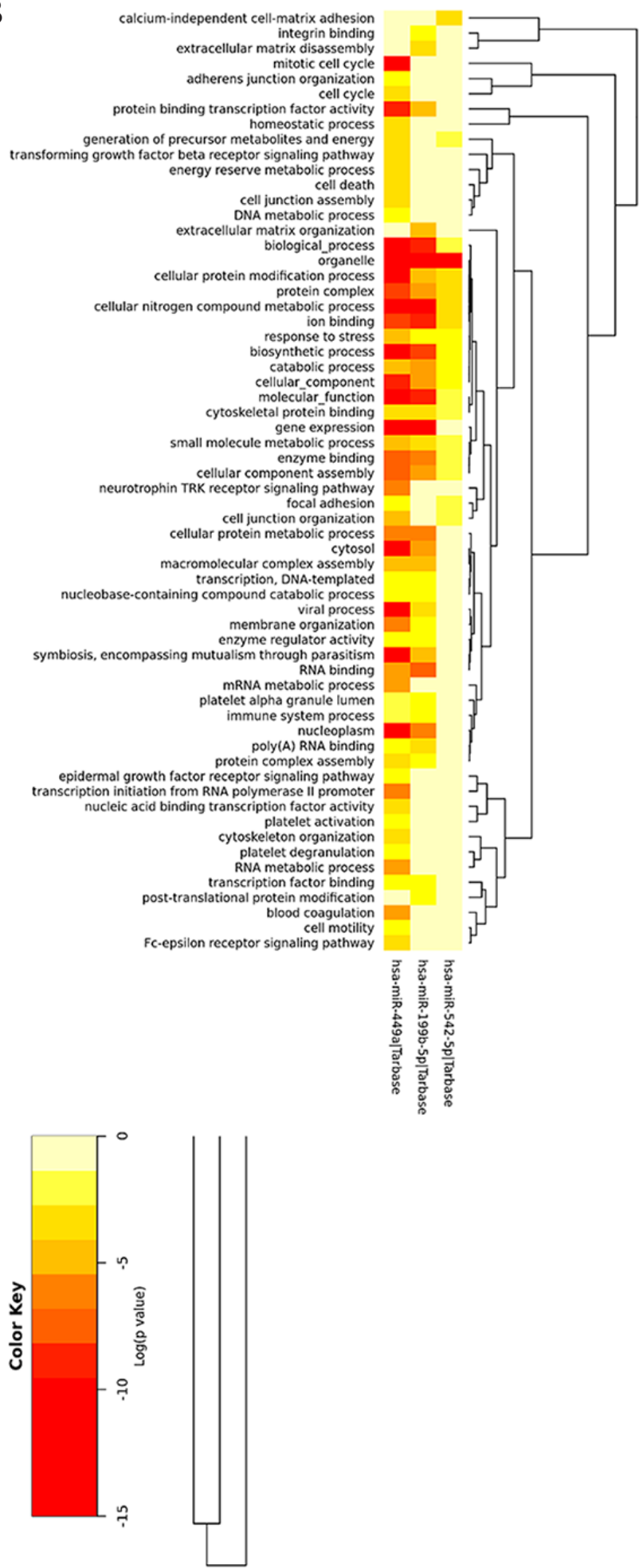

Figure 7: Heatmap of pathway analysis of miRNA449a, 199-5p and 542-5p by KEGG pathway A. and GO categories B. 
Table 3: pathway analysis of miRNA449a, 199b-5p, 542-5p.

\begin{tabular}{|c|c|c|c|c|c|}
\hline pathway analysis & $p$ & $\begin{array}{l}\text { no. of target } \\
\text { genes }\end{array}$ & $\begin{array}{l}\text { miRNA } \\
-449 a\end{array}$ & $\begin{array}{l}\text { miRNA- } \\
199 b-5 p\end{array}$ & $\begin{array}{l}\text { miRNA- } \\
542-5 p\end{array}$ \\
\hline \multicolumn{6}{|l|}{ KEGG pathway } \\
\hline Fatty acid biosynthesis & 0 & 3 & $\mathrm{Y}$ & $\mathrm{N}$ & $\mathrm{Y}$ \\
\hline Fatty acid metabolism & 0 & 3 & $\mathrm{Y}$ & $\mathrm{N}$ & $\mathrm{Y}$ \\
\hline ECM-receptor interaction & 0 & 10 & $\mathrm{~N}$ & $\mathrm{Y}$ & $\mathrm{Y}$ \\
\hline Proteoglycans in cancer & $2.47 \mathrm{E}-07$ & 15 & $\mathrm{Y}$ & $\mathrm{Y}$ & $\mathrm{N}$ \\
\hline Central carbon metabolism in cancer & $1.58 \mathrm{E}-06$ & 14 & $\mathrm{Y}$ & $\mathrm{Y}$ & $\mathrm{N}$ \\
\hline \multicolumn{6}{|l|}{ GO Category } \\
\hline molecular function & 0 & 789 & $\mathrm{Y}$ & $\mathrm{Y}$ & $\mathrm{Y}$ \\
\hline cellular protein modification process & 0 & 155 & $\mathrm{Y}$ & $\mathrm{Y}$ & $\mathrm{Y}$ \\
\hline biological process & 0 & 780 & $\mathrm{Y}$ & $\mathrm{Y}$ & $\mathrm{Y}$ \\
\hline biosynthetic process & 0 & 255 & $\mathrm{Y}$ & $\mathrm{Y}$ & $\mathrm{Y}$ \\
\hline $\begin{array}{l}\text { cellular nitrogen compound metabolic } \\
\text { process }\end{array}$ & 0 & 299 & $\mathrm{Y}$ & $\mathrm{Y}$ & $\mathrm{Y}$ \\
\hline ion binding & 0 & 317 & $\mathrm{Y}$ & $\mathrm{Y}$ & $\mathrm{Y}$ \\
\hline organelle & 0 & 596 & $\mathrm{Y}$ & $\mathrm{Y}$ & $\mathrm{Y}$ \\
\hline protein complex & $1.33 \mathrm{E}-15$ & 232 & $\mathrm{Y}$ & $\mathrm{Y}$ & $\mathrm{Y}$ \\
\hline cellular component & $5.00 \mathrm{E}-15$ & 784 & $\mathrm{Y}$ & $\mathrm{Y}$ & $\mathrm{Y}$ \\
\hline enzyme binding & $2.80 \mathrm{E}-13$ & 103 & $\mathrm{Y}$ & $\mathrm{Y}$ & $\mathrm{Y}$ \\
\hline cellular component assembly & $5.09 \mathrm{E}-12$ & 102 & $\mathrm{Y}$ & $\mathrm{Y}$ & $\mathrm{Y}$ \\
\hline catabolic process & $2.86 \mathrm{E}-10$ & 126 & $\mathrm{Y}$ & $\mathrm{Y}$ & $\mathrm{Y}$ \\
\hline response to stress & $4.90 \mathrm{E}-08$ & 136 & $\mathrm{Y}$ & $\mathrm{Y}$ & $\mathrm{Y}$ \\
\hline cytoskeletal protein binding & $1.68 \mathrm{E}-07$ & 61 & $\mathrm{Y}$ & $\mathrm{Y}$ & $\mathrm{Y}$ \\
\hline small molecule metabolic process & $2.90 \mathrm{E}-07$ & 130 & $\mathrm{Y}$ & $\mathrm{Y}$ & $\mathrm{Y}$ \\
\hline gene expression & 0 & 70 & $\mathrm{Y}$ & $\mathrm{Y}$ & $\mathrm{N}$ \\
\hline $\begin{array}{l}\text { symbiosis, encompassing mutualism } \\
\text { through parasitism }\end{array}$ & 0 & 58 & $\mathrm{Y}$ & $\mathrm{Y}$ & $\mathrm{N}$ \\
\hline nucleoplasm & $2.22 \mathrm{E}-16$ & 97 & $\mathrm{Y}$ & $\mathrm{Y}$ & $\mathrm{N}$ \\
\hline cytosol & $1.89 \mathrm{E}-15$ & 174 & $\mathrm{Y}$ & Y & $\mathrm{N}$ \\
\hline viral process & $1.43 \mathrm{E}-14$ & 50 & $\mathrm{Y}$ & $\mathrm{Y}$ & $\mathrm{N}$ \\
\hline RNA binding & $2.72 \mathrm{E}-12$ & 122 & $\mathrm{Y}$ & $\mathrm{Y}$ & $\mathrm{N}$ \\
\hline cellular protein metabolic process & 4.33E-12 & 43 & $\mathrm{Y}$ & $\mathrm{Y}$ & $\mathrm{N}$ \\
\hline $\begin{array}{l}\text { protein binding transcription factor } \\
\text { activity }\end{array}$ & $6.72 \mathrm{E}-12$ & 49 & $\mathrm{Y}$ & $\mathrm{Y}$ & $\mathrm{N}$ \\
\hline macromolecular complex assembly & $1.36 \mathrm{E}-08$ & 64 & $\mathrm{Y}$ & Y & $\mathrm{N}$ \\
\hline membrane organization & $9.90 \mathrm{E}-08$ & 45 & $\mathrm{Y}$ & $\mathrm{Y}$ & $\mathrm{N}$ \\
\hline cell junction organization & $5.04 \mathrm{E}-06$ & 18 & $\mathrm{Y}$ & $\mathrm{N}$ & $\mathrm{Y}$ \\
\hline poly(A) RNA binding & $5.87 \mathrm{E}-06$ & 103 & $\mathrm{Y}$ & Y & $\mathrm{N}$ \\
\hline protein complex assembly & $2.17 \mathrm{E}-05$ & 52 & $\mathrm{Y}$ & $\mathrm{Y}$ & $\begin{array}{l}\mathrm{N} \\
\text { (Continued) }\end{array}$ \\
\hline
\end{tabular}




\begin{tabular}{lccccc}
\hline pathway analysis & $\boldsymbol{p}$ & $\begin{array}{c}\text { no. of target } \\
\text { genes }\end{array}$ & $\begin{array}{c}\text { miRNA } \\
\mathbf{- 4 4 9 a}\end{array}$ & $\begin{array}{c}\text { miRNA- } \\
\mathbf{1 9 9} \mathbf{b - 5 p}\end{array}$ & $\begin{array}{c}\text { miRNA- } \\
\mathbf{5 4 2 - 5 p}\end{array}$ \\
\hline transcription, DNA-templated & $9.55 \mathrm{E}-05$ & 127 & $\mathrm{Y}$ & $\mathrm{Y}$ & $\mathrm{N}$ \\
$\begin{array}{l}\text { nucleobase-containing compound } \\
\text { catabolic process }\end{array}$ & 0.000168 & 53 & $\mathrm{Y}$ & $\mathrm{Y}$ & $\mathrm{N}$ \\
enzyme regulator activity & & & & $\mathrm{N}$ \\
transcription factor binding & 0.000207 & 51 & $\mathrm{Y}$ & $\mathrm{Y}$ & $\mathrm{N}$ \\
$\begin{array}{l}\text { generation of precursor metabolites } \\
\text { and energy }\end{array}$ & 0.000255 & 43 & $\mathrm{Y}$ & $\mathrm{Y}$ & $\mathrm{N}$ \\
focal adhesion & 0.0004 & 20 & $\mathrm{Y}$ & $\mathrm{N}$ & $\mathrm{Y}$ \\
immune system process & 0.000601 & 35 & $\mathrm{Y}$ & $\mathrm{N}$ & $\mathrm{Y}$ \\
$\begin{array}{l}\text { activation of signaling protein activity } \\
\text { involved in unfolded protein response }\end{array}$ & 0.002297 & 91 & $\mathrm{Y}$ & $\mathrm{Y}$ & $\mathrm{N}$ \\
platelet alpha granule lumen & 0.003495 & 7 & $\mathrm{Y}$ & $\mathrm{Y}$ & $\mathrm{N}$ \\
\hline
\end{tabular}

Table 4: miRNAs with relative expression level associated with poor prognosis, their function and target or related gene.

\begin{tabular}{|c|c|c|c|}
\hline miRNA & $\begin{array}{c}\text { Expression } \\
\text { level } \\
\text { associate } \\
\text { with poor } \\
\text { prognosis }\end{array}$ & Function & Target or related gene \\
\hline $\operatorname{miR}-210[10]$ & high & Oncogene (Tumor Initiation) & $\mathrm{N} / \mathrm{D}$ \\
\hline miR-17-92[19] & high & Oncogene (Tumor Progression) & $\mathrm{N} / \mathrm{D}$ \\
\hline $\operatorname{miR}-128[23]$ & high & Oncogene & Inhibits PTEN \\
\hline $\operatorname{miR}-9[27]$ & high & Oncogene Promote metastasis & $\mathrm{N} / \mathrm{D}$ \\
\hline $\operatorname{miR}-214[26]$ & high & Oncogene (Tumor Progression) & $\mathrm{N} / \mathrm{D}$ \\
\hline $\operatorname{miR}-542-5 p[14]$ & high & Oncogene & Inhibits HUWE1 \\
\hline miR-130b [29] & high & Oncogene (Tumor Progression) & Inhibits PPAR $\gamma$ \\
\hline $\operatorname{miR}-130 \mathrm{a}[12]$ & high & Oncogene Promote metastasis & Inhibits PTEN \\
\hline miR-199b-5p [31] & high & Oncogene & HES1 \\
\hline $\operatorname{miR}-132[28]$ & low & $\begin{array}{l}\text { Discriminate good responders from poor } \\
\text { responders }\end{array}$ & $\mathrm{N} / \mathrm{D}$ \\
\hline $\operatorname{miR}-145$ [22] & low & $\begin{array}{l}\text { Tumor suppressor Discriminate good responders } \\
\text { from poor responders }\end{array}$ & $\mathrm{N} / \mathrm{D}$ \\
\hline $\operatorname{miR}-382$ [20] & low & Oncogene Suppress metastasis & Stabilize MYC \\
\hline miR-133a [18] & low & $\begin{array}{c}\text { Tumor suppressor Suppress pulmonary } \\
\text { metastasis }\end{array}$ & Inhibits Bcl-xL, Mcl-1 \\
\hline $\operatorname{miR}-26 a[21]$ & low & $\begin{array}{c}\text { Tumor suppressor Suppress metastasis and } \\
\text { recurrence }\end{array}$ & Inhibits EZH2 \\
\hline $\operatorname{miR}-340[11]$ & low & Tumor suppressor Suppress metastasis & $\mathrm{N} / \mathrm{D}$ \\
\hline miR-20a [9] & low & Tumor suppressor & Inhibits FAS \\
\hline miR-92a [9] & low & Discriminate ifosfamide responder & $\begin{array}{l}\text { Inhibits FAS } \\
\qquad \text { (Con }\end{array}$ \\
\hline
\end{tabular}




\begin{tabular}{lccc}
\hline miRNA & $\begin{array}{c}\text { Expression } \\
\text { level } \\
\text { associate } \\
\text { with poor } \\
\text { prognosis }\end{array}$ & Function & Target or related gene \\
\hline miR-143 [33] & low & Tumor suppressor Suppress pulmonary & MMP-13 Bcl-2 \\
miR-451 [30] & metastasis & N/D \\
miR-144 [25] & low & Tumor suppressor & Inhibits ROCK1, ROCK2 \\
miR-22 [24] & Tumor suppressor Suppress metastasis & Inhibits HMGB1 \\
miR-195 [17] & low & Tumor suppressor & Inhibits CCND1 \\
miR-124 [16] & low & Suppress metastasis & N/D \\
miR-449a [13] & low & Tumor suppressor & Inhibits Bcl-2 \\
miR-99a [32] & low & Tumor suppressor & mTOR \\
miR-224 [15] & Low & Tumor suppressor & Rac1 \\
\hline
\end{tabular}

- N/D, not determined; PTEN, phosphatase and tensin homolog; HUWE1; PPAR $\gamma$, peroxisome proliferator-activated receptor gamma; HES1, hes family bHLH transcription factor 1; MYC, v-myc avian myelocytomatosis viral oncogene homolog ; Bcl-xL, BCL2-like 1 isoform 1; Mcl-1, BCL2 family apoptosis regulator; EZH2, enhancer of zeste 2 polycomb repressive complex 2 subunit; FAS, tumor necrosis factor receptor superfamily member 6 ; MMP-13, matrix metallopeptidase 13; Bcl-2, B-cell lymphoma 2; ROCK, Rho-associated protein kinase; HMGB1, high mobility group box 1; CCND1, Cyclin D1; MTOR, mechanistic target of rapamycin; Rac1, Ras-related C3 botulinum toxin substrate 1

osteosarcoma metastasis [38]. Pathways related to other malignancies were found in this analysis, such as breast cancer, and prostate cancer [38-41]. The target genes of miRNAs in various cancers may overlap, which suggest that miRNAs could be promising therapeutic targets in cancer treatment.

In this study, we investigated the prognostic value of miRNA in patients with osteosarcoma using a meta-analysis approach. Finally, we concluded that decreased miRNA expression in tumor tissue is associated with worse outcome of patients with osteosarcoma. However, we should also pay attention to increased expression of several miRNAs in tumor tissue of osteosarcoma. Furthermore, prospective studies with a large sample size are warranted to clarify the prognostic role of miRNAs in osteosarcoma.

\section{MATERIALS AND METHODS}

\section{Data search and study election}

We performed a systematic search if MEDLINE (from inception to August 2016) and EMBASE (from inception to August 2016) for English-language publications using the keywords "osteosarcoma", "miRNA", "prognosis". All searches were limited to human studies. The inclusion criteria were studies of osteosarcoma that reported the results of miRNA expressions and survival data. Reviews, abstracts, and editorial materials were excluded. Two authors performed the searches and screening independently, and discrepancies were resolved by consensus.

\section{Data extraction and statistical analysis}

Data were extracted from the publications independently by two reviewers, and the following information was recorded: first author, year of publication, country, miRNA expression analyzed, number of patients, staging, and end points. The primary outcome was OS, which was defined as the time from the initiation of therapy until death from any cause. The secondary end point was EFS. Data regarding diseasefree survival (DFS), progression-free survival (PFS), recurrence-free survival (RFS) were obtained from the included studies, and were redefined as EFS, which was measured from the date of initiation of therapy to the date of recurrence or metastasis $[42,43]$.

The effects of miRNA expressions on survival were assessed using hazard ratios. Survival data were extracted following a methodology suggested previously [44]. A univariate HR estimate and 95\% CIs were extracted directly from each study, if provided by the authors. Otherwise, $p$ values of the log-rank tests, 95\% confidence intervals, number of events, and numbers of patients at risk were extracted to estimate the HR indirectly. Survival rates calculated from Kaplan-Meier curves were read using 
Engauge Digitizer version 3.0 (http://digitizer.sourceforge. net) to reconstruct the HR estimate and its variance, assuming that patients were censored at a constant rate during followup. The HRs were calculated on the basis of low expression of miRNA, which means HR $>1$ and $<1$ implied poor and good prognosis for patients with low miRNA expression. Heterogeneity among studies was assessed using $\chi^{2}$ tests and $\mathrm{I}^{2}$ statistics, as described previously [45]. Funnel plots were used to assess publication bias [46]. $p$ values $<0.05$ were considered to be statistically significant. The data from each study were analyzed using Review Manager (RevMan, Version 5.3 Copenhagen: The Nordic Cochrane Centre, The Cochrane Collaboration, 2014). miRNA target genes and related pathways were predicted by DIANA-mirPath v3.0 (http://www.microrna.gr/miRPathv3) based on Tarbase, KEGG and GO [34] to interpret functional value of miRNAs.

\section{CONFLICTS OF INTEREST}

None.

\section{FUNDING}

This study was supported by 2016 Post-Doc. Development Program of Pusan National University, Basic Science Research Program through the National Research Foundation of Korea (NRF) funded by the Ministry of Education (NRF-2016R1A6A3A11931738) and Basic Science Research Program through the National Research Foundation of Korea (NRF) funded by the Ministry of Education (NRF-2015R1D1A1A01059035).

\section{Author contributions}

Yun Hak Kim: write the manuscript

Tae Sik Goh, Chi-Seung Lee: study design

Sae Ock Oh, Jeung Il Kim, Seung Hyeon Jeung: statistical analysis

Kyoungjune Pak; write the manuscript

\section{REFERENCES}

1. Geller DS and Gorlick R. Osteosarcoma: a review of diagnosis, management, and treatment strategies. Clin Adv Hematol Oncol. 2010; 8:705-718.

2. Luetke A, Meyers PA, Lewis I and Juergens $H$. Osteosarcoma treatment - where do we stand? A state of the art review. Cancer Treat Rev. 2014; 40:523-532.

3. Sassen S, Miska EA and Caldas C. MicroRNA: implications for cancer. Virchows Arch. 2008; 452:1-10.

4. Wang Y, Keys DN, Au-Young JK and Chen C. MicroRNAs in embryonic stem cells. J Cell Physiol. 2009; 218:251-255.

5. Zhao G, Cai C, Yang T, Qiu X, Liao B, Li W, Ji Z, Zhao J, Zhao H, Guo M, Ma Q, Xiao C, Fan Q and Ma B. MicroRNA-221 induces cell survival and cisplatin resistance through $\mathrm{PI} 3 \mathrm{~K} / \mathrm{Akt}$ pathway in human osteosarcoma. PLoS One. 2013; 8:e53906.

6. Adams BD, Kasinski AL and Slack FJ. Aberrant regulation and function of microRNAs in cancer. Curr Biol. 2014; 24:R762-776.

7. Bottai G, Pasculli B, Calin GA and Santarpia L. Targeting the microRNA-regulating DNA damage/repair pathways in cancer. Expert Opin Biol Ther. 2014; 14:1667-1683.

8. Nugent M. MicroRNA function and dysregulation in bone tumors: the evidence to date. Cancer Manag Res. 2014; 6:15-25.

9. Arabi L, Gsponer JR, Smida J, Nathrath M, Perrina V, Jundt G, Ruiz C, Quagliata L and Baumhoer D. Upregulation of the miR-17-92 cluster and its two paraloga in osteosarcoma - reasons and consequences. Genes Cancer. 2014; 5:56-63. doi: 10.18632/genesandcancer.6.

10. Cai H, Lin L, Cai H, Tang M and Wang Z. Prognostic evaluation of microRNA-210 expression in pediatric osteosarcoma. Med Oncol. 2013; 30:499.

11. Cai H, Lin L, Cai H, Tang M and Wang Z. Combined microRNA-340 and ROCK1 mRNA profiling predicts tumor progression and prognosis in pediatric osteosarcoma. Int J Mol Sci. 2014; 15:560-573.

12. Chen J, Yan D, Wu W, Zhu J, Ye W and Shu Q. MicroRNA$130 \mathrm{a}$ promotes the metastasis and epithelial-mesenchymal transition of osteosarcoma by targeting PTEN. Oncol Rep. 2016; 35:3285-3292.

13. Chen J, Zhou J, Chen X, Yang B, Wang D, Yang P, He X and Li H. miRNA-449a is downregulated in osteosarcoma and promotes cell apoptosis by targeting BCL2. Tumour Biol. 2015; 36:8221-8229.

14. Cheng DD, Yu T, Hu T, Yao M, Fan CY and Yang QC. MiR-542-5p is a negative prognostic factor and promotes osteosarcoma tumorigenesis by targeting HUWE1. Oncotarget. 2015; 6:42761-42772. doi: 10.18632/oncotarget.6199.

15. Geng S, Gu L, Ju F, Zhang H, Wang Y, Tang H, Bi Z and Yang C. MicroRNA-224 promotes the sensitivity of osteosarcoma cells to cisplatin by targeting Rac1. J Cell Mol Med. 2016; 20:1611-1619.

16. Kinahan PE, Mankoff DA and Linden HM. The Value of Establishing the Quantitative Accuracy of PET/CT Imaging. Journal of nuclear medicine. 2015; 56:1133-1134.

17. Han K, Chen X, Bian N, Ma B, Yang T, Cai C, Fan Q, Zhou $\mathrm{Y}$ and Zhao TB. MicroRNA profiling identifies MiR195 suppresses osteosarcoma cell metastasis by targeting CCND1. Oncotarget. 2015; 6:8875-8889. doi: 10.18632/ oncotarget.3560.

18. Ji F, Zhang H, Wang Y, Li M, Xu W, Kang Y, Wang Z, Wang Z, Cheng P, Tong D, Li C and Tang H. MicroRNA-133a, downregulated in osteosarcoma, suppresses proliferation and promotes apoptosis by targeting Bcl-xL and Mcl-1. Bone. 2013; 56:220-226.

19. Li X, Yang H, Tian Q, Liu Y and Weng Y. Upregulation of microRNA-17-92 cluster associates with tumor progression and prognosis in osteosarcoma. Neoplasma. 2014; 61:453-460. 
20. Sarver AL, Thayanithy V, Scott MC, Cleton-Jansen AM, Hogendoorn PC, Modiano JF and Subramanian S. MicroRNAs at the human 14q32 locus have prognostic significance in osteosarcoma. Orphanet J Rare Dis. 2013; 8:7.

21. Song QC, Shi ZB, Zhang YT, Ji L, Wang KZ, Duan DP and Dang XQ. Downregulation of microRNA-26a is associated with metastatic potential and the poor prognosis of osteosarcoma patients. Oncol Rep. 2014; 31:1263-1270.

22. Tang M, Lin L, Cai H, Tang J and Zhou Z. MicroRNA-145 downregulation associates with advanced tumor progression and poor prognosis in patients suffering osteosarcoma. Onco Targets Ther. 2013; 6:833-838.

23. Tian Z, Guo B, Yu M, Wang C, Zhang H, Liang Q, Jiang $\mathrm{K}$ and Cao L. Upregulation of micro-ribonucleic acid128 cooperating with downregulation of PTEN confers metastatic potential and unfavorable prognosis in patients with primary osteosarcoma. Onco Targets Ther. 2014; 7:1601-1608.

24. Wang G, Shen N, Cheng L, Lin J and Li K. Downregulation of miR-22 acts as an unfavorable prognostic biomarker in osteosarcoma. Tumour Biol. 2015; 36:7891-7895.

25. Wang W, Zhou X and Wei M. MicroRNA-144 suppresses osteosarcoma growth and metastasis by targeting ROCK1 and ROCK2. Oncotarget. 2015; 6:10297-10308. doi: 10.18632/oncotarget.3305.

26. Wang Z, Cai H, Lin L, Tang M and Cai H. Upregulated expression of microRNA-214 is linked to tumor progression and adverse prognosis in pediatric osteosarcoma. Pediatr Blood Cancer. 2014; 61:206-210.

27. Xu SH, Yang YL, Han SM and Wu ZH. MicroRNA-9 expression is a prognostic biomarker in patients with osteosarcoma. World J Surg Oncol. 2014; 12:195.

28. Yang J, Gao T, Tang J, Cai H, Lin L and Fu S. Loss of microRNA-132 predicts poor prognosis in patients with primary osteosarcoma. Mol Cell Biochem. 2013; 381:9-15.

29. Yu LD, Jin RL, Gu PC, Ling ZH, Lin XJ and Du JY. Clinical significance of microRNA-130b in osteosarcoma and in cell growth and invasion. Asian Pac J Trop Med. 2015; 8:752-756.

30. Yuan J, Lang J, Liu C, Zhou K, Chen L and Liu Y. The expression and function of miRNA-451 in osteosarcoma. Med Oncol. 2015; 32:324.

31. Zeng H, Zhang Z, Dai X, Chen Y, Ye J and Jin Z. Increased Expression of microRNA-199b-5p Associates with Poor Prognosis Through Promoting Cell Proliferation, Invasion and Migration Abilities of Human Osteosarcoma. Pathol Oncol Res. 2016; 22:253-260.

32. Zhao J, Chen F, Zhou Q, Pan W, Wang X, Xu J, Ni L and Yang H. Aberrant expression of microRNA-99a and its target gene mTOR associated with malignant progression and poor prognosis in patients with osteosarcoma. Onco Targets Ther. 2016; 9:1589-1597.

33. Zhou J, Wu S, Chen Y, Zhao J, Zhang K, Wang J and Chen S. microRNA-143 is associated with the survival of ALDH1+CD133+ osteosarcoma cells and the chemoresistance of osteosarcoma. Exp Biol Med (Maywood). 2015; 240:867-875.

34. Vlachos IS, Paraskevopoulou MD, Karagkouni D, Georgakilas G, Vergoulis T, Kanellos I, Anastasopoulos IL, Maniou S, Karathanou K, Kalfakakou D, Fevgas A, Dalamagas T and Hatzigeorgiou AG. DIANA-TarBase v7.0: indexing more than half a million experimentally supported miRNA:mRNA interactions. Nucleic Acids Res. 2015; 43:D153-159.

35. Michiels S, Piedbois P, Burdett S, Syz N, Stewart L and Pignon JP. Meta-analysis when only the median survival times are known: a comparison with individual patient data results. Int J Technol Assess Health Care. 2005; 21:119-125.

36. Yang Z, Zhang Y, Zhang X, Zhang M, Liu H, Zhang S, Qi B and Sun X. Serum microRNA-221 functions as a potential diagnostic and prognostic marker for patients with osteosarcoma. Biomed Pharmacother. 2015; 75:153-158.

37. Dong J, Liu Y, Liao W, Liu R, Shi P and Wang L. miRNA223 is a potential diagnostic and prognostic marker for osteosarcoma. J Bone Oncol. 2016; 5:74-79.

38. Liu SJ, Zhi H, Chen PZ, Chen W, Lu F, Ma GS, Dai JC, Shen C, Liu NF, Hu ZB, Wang H and Shen HB. Fatty acid desaturase 1 polymorphisms are associated with coronary heart disease in a Chinese population. Chin Med J (Engl). 2012; 125:801-806.

39. Currie E, Schulze A, Zechner R, Walther TC and Farese RV, Jr. Cellular fatty acid metabolism and cancer. Cell Metab. 2013; 18:153-161.

40. Nikitovic D, Berdiaki K, Chalkiadaki G, Karamanos N and Tzanakakis G. The role of SLRP-proteoglycans in osteosarcoma pathogenesis. Connect Tissue Res. 2008; 49:235-238.

41. Richardson AD, Yang C, Osterman A and Smith JW. Central carbon metabolism in the progression of mammary carcinoma. Breast Cancer Res Treat. 2008; 110:297-307.

42. Pak K, Suh S, Kim SJ and Kim IJ. Prognostic value of genetic mutations in thyroid cancer: a meta-analysis. Thyroid. 2015; 25:63-70.

43. Zhao Q, Feng Y, Mao X and Qie M. Prognostic value of fluorine-18-fluorodeoxyglucose positron emission tomography or PET-computed tomography in cervical cancer: a meta-analysis. Int J Gynecol Cancer. 2013; 23:1184-1190.

44. Parmar MK, Torri V and Stewart L. Extracting summary statistics to perform meta-analyses of the published literature for survival endpoints. Stat Med. 1998; 17:2815-2834.

45. Higgins JP, Thompson SG, Deeks JJ and Altman DG. Measuring inconsistency in meta-analyses. BMJ. 2003; 327:557-560.

46. Egger M, Davey Smith G, Schneider M and Minder C. Bias in meta-analysis detected by a simple, graphical test. BMJ. 1997; 315:629-634. 